\title{
Potency of Rhodotorula minuta as Plant Growth Promoter on Red Chili Plant Infected by Colletotrichum acutatum
}

\author{
Sri Hartati ${ }^{{ }^{*}}$, Linda Tarina ${ }^{2}$, Endah Yulia ${ }^{1}$, Luciana Djaya ${ }^{1}$ \\ ${ }^{1}$ Department of Plant Pests and Diseases, Agriculture Faculty, Universitas Padjadjaran, Jatinangor, West Java, \\ Indonesia, 45363 \\ ${ }^{2}$ Alumny of Department of Plant Pests and Diseases, Agriculture Faculty, Universitas Padjadjaran, Jatinangor, West Java, \\ Indonesia, 45363 \\ *Corresponding Author: s.hartati@unpad.ac.id
}

Received July 14, 2019; revised July 19, 2019; accepted September 17, 2019

\begin{abstract}
Some yeast species were reported to have the ability to promote plant growth. Rhodotorula minuta is a yeast species that has the potency as biocontrol agent. This research was objected to evaluate the potency of $R$. minuta in promoting the growth of red chilli infected by Colletotrichum acutatum. The experiment was carried out at the Laboratory of Plant Protection Biotechnology and Green House of Ciparanje Experiment Station, Faculty of Agriculture, Universitas Padjadjaran. The experiment was arranged in the randomized completely block design with 9 treatments and 5 replications. The treatments were infestation of $R$. minuta and inoculation of $C$. acutatum on 5, 7, and 10 days after replanting, and a positive control with no $R$. minuta infestation but inoculated with the pathogen and a negative control without $R$. minuta infestation nor pathogen inoculation. Results of the experiment showed that the effectiveness of the treatments with $R$. minuta on the increase of the chilli plant height was $3.78-17.90 \%$, leaf number was $4.09-15.19 \%$, and dry weight of the biomass was $0.14-0.58 \%$. This results indicated that treatments with $R$. minuta were able to promote the growth of chilli plants.
\end{abstract}

Keywords: antagonistic agents, effectiveness, plant dry weight, yeast

\section{ABSTRAK}

Potensi Rhodotorula minuta sebagai Pemacu Pertumbuhan Cabai Merah yang Terinokulasi Colletotrichum acutatum

Rhodotorula minuta merupakan salah satu khamir yang berpotensi sebagai agens biokontrol. Beberapa khamir telah dilaporkan memiliki kemampuan sebagai pemacu pertumbuhan tanaman. Penelitian ini bertujuan untuk mengetahui kemampuan $R$. minuta dalam memacu pertumbuhan tanaman cabai yang terinfeksi Colletotrichum acutatum. Penelitian dilakukan di Laboratorium Bioteknologi Proteksi Tanaman dan Rumah Kaca Kebun Percobaan Ciparanje, Fakultas Pertanian, Universitas Padjadjaran. Penelitian menggunakan Rancangan Acak Kelompok (RAK) dengan 9 perlakuan dan 5 ulangan. Perlakuan adalah infestasi agens hayati $R$. minuta dan inokulasi $C$. acutatum pada 5, 7, dan 10 hari setelah pindah tanam (hst) ditambah kontrol (+) tanpa infestasi tetapi diinokulasi patogen dan kontrol (-) tanpa infestasi dan inokulasi patogen. Hasil penelitian menunjukkan bahwa nilai keefektifan peningkatan pertumbuhan tanaman cabai dengan perlakuan R. minuta berkisar antara 3,78-17,90\% untuk tinggi tanaman, 4,09-15,19\% untuk jumlah daun, dan 0,14-0,58\% untuk bobot biomasa kering. Hasil ini menunjukkan bahwa perlakuan $R$. minuta cenderung meningkatkan pertumbuhan tanaman cabai.

Keywords: Agens antagonis, bobot kering, khamir, nilai keefektifan

\section{PENDAHULUAN}

Cabai merah (Capsicum annuum L.) merupakan salah satu komoditas hortikultura yang memiliki nilai ekonomi tinggi. Produktivitas cabai merah di Indonesia masih di bawah potensi produktivitas yang dapat mencapai 12-15 ton/ha (Duriat \& Agus, 2003). Produktivitas cabai merah yang rendah ini dapat disebabkan oleh berbagai kendala diantaranya serangan patogen penyebab penyakit.

Serangan patogen dapat menyebabkan terhambatnya pertumbuhan tanaman yang selanjutnya dapat berpengaruh terhadap produktivitas tanaman, disamping patogen menyebabkan kerusakan secara langsung terhadap produk tanaman. Antraknosa yang disebabkan oleh Colletotrichum acutatum merupakan salah satu penyakit penting pada tanaman cabai. Patogen antraknosa ini dapat menyerang pada bagian buah, daun, batang, dan biji (Nayaka et al., 2009). Kerusakan pada daun dapat mengurangi potensi daun dalam berfotosintesis sehingga dapat mengganggu pertumbuhan tanaman. Serangan $C$. acutatum pada daun dapat menimbulkan gejala nekrosis. Gejala nekrosis pada daun akibat patogen ini dapat meluas (Stankova et al., 2011) sehingga menurunkan proses fotosintesis yang selanjutnya dapat menurunkan pertumbuhan dan produksi tanaman yang terinfeksi. Perlindungan terhadap infeksi dapat dilakukan dengan menekan patogen secara langsung maupun secara tidak langsung dengan meningkatkan pertumbuhan tanaman. Hal ini perlu dilakukan untuk 
mempertahankan kualitas dan kuantitas produksi tanaman.

Pertumbuhan tanaman dapat dipengaruhi oleh beberapa faktor. Mikrob merupakan salah satu faktor yang dapat memacu pertumbuhan tanaman. Mikrob yang telah dilaporkan mampu meningkatkan pertumbuhan tanaman adalah bakteri dan jamur termasuk khamir. Beberapa jamur dan khamir diketahui memiliki kemampuan dalam meningkatkan pertumbuhan tanaman, seperti Trichoderma spp. (Sundaramoorthy \& Balabaskar, 2013), Aureobasidium pullulans (Ignatova et al., 2015) dan Williopsis saturnus (Nassar et al., 2005). Fu et al. (2016) melaporkan bahwa beberapa khamir mampu menghasilkan IAA seperti Aureobasidium pullulans, Candida sp., Dothideomycetes sp., Saccharomyces cerevisiae, Cryptococcus laurentii, dan Pseudozyma aphidis. Khamir dari genus Candida telah dilaporkan dapat berperan sebagai pelarut fosfat dan dekomposer (Alami et al., 2017). Kombinasi Candida dengan Bacillus mampu meningkatkan pertumbuhan tanaman dibandingkan dengan perlakuan pupuk hayati lainnya (Alami et al., 2017). Khamir Candida tropicalis HY yang diisolasi dari tanah dilaporkan juga mampu menghasilkan IAA dan memiliki aktivitas ACC deaminase yang tinggi serta menghasilkan polyamine dan phytase (Amprayn et al., 2012).

Khamir Rhodotorula minuta merupakan salah satu khamir yang telah diketahui memiliki kemampuan sebagai agens antagonis patogen penyebab penyakit tanaman. Khamir ini mampu menekan antraknosa pada cabai yang disebabkan oleh C. acutatum sebesar $90,17 \%$ melalui mekanisme pembentukan senyawa volatil, hiperparasitisme, dan pembentukan enzim ACC deaminase (Hartati, 2016). Akan tetapi, kemampuan $R$. minuta tersebut dalam meningkatkan pertumbuhan cabai belum diketahui. Penelitian ini bertujuan untuk mengetahui potensi khamir $R$. minuta dalam meningkatkan pertumbuhan cabai yang terinfeksi $C$. acutatum.

\section{BAHAN DAN METODE}

Penelitian dilaksanakan di Laboratorium Bioteknologi Proteksi Tanaman, Departemen Hama dan Penyakit Tumbuhan, dan rumah kaca Kebun Percobaan Ciparanje, Fakultas Pertanian, Universitas Padjadjaran. Penelitian dilaksanakan dengan menggunakan Rancangan Acak Kelompok (RAK) dengan 9 perlakuan dan 5 ulangan. Perlakuan pada penelitian ini menggunakan teknik perendaman benih dan penyiraman bibit cabai dengan suspensi $R$ minuta dengan waktu inokulasi patogen $C$. acutatum yang berbeda. Perlakuan tersebut adalah sebagai berikut :

A = Infestasi $R$. minuta dan inokulasi $C$. acutatum 3 hari setelah pindah tanam (hst)

$\mathrm{B}=$ Infestasi $R$. minuta dan inokulasi $C$. acutatum 5 hst

$\mathrm{C}=$ Infestasi $R$. minuta dan inokulasi $C$. acutatum 7 hst
$\mathrm{D}=$ Infestasi $R$. minuta dan inokulasi $C$. acutatum 10 hst

$\mathrm{E}=$ Kontrol (+) tanpa infestasi $R$. minuta, inokulasi $C$. acutatum 3 hst

$\mathrm{F}=$ Kontrol (+) tanpa infestasi $R$. minuta, inokulasi $C$. acutatum 5 hst

$\mathrm{G}=$ Kontrol (+) tanpa infestasi R. minuta, inokulasi $C$. acutatum 7 hst

$\mathrm{H}=$ Kontrol (+) tanpa infestasi $R$. minuta, inokulasi $C$. acutatum 10 hst

I = Kontrol (-) tanpa infestasi R. minuta dan inokulasi C. acutatum

\section{Penyediaan $R$. minuta dan $C$. acutatum}

Spesies khamir $R$. minuta diperoleh dari cabai di Darmaga Bogor, sedangkan isolat $C$. acutatum diperoleh dari pertanaman cabai di Sumedang. Khamir diremajakan dalam media Yeast Malt Extract broth (YMB), selanjutnya ditumbuhkan pada media Potato Dextrose Agar (PDA). Isolat $C$. acutatum ditumbuhkan pada media PDA. Koloni khamir yang tumbuh selanjutnya dibuat suspensi dengan kerapatan sel $10^{8} \mathrm{sel} \mathrm{ml}^{-1}$. Kerapatan sel khamir dihitung dengan menggunakan hemositometer. Penyediaan $C$. acutatum dilakukan seperti pada pembuatan suspensi khamir, dengan kerapatan konidia $10^{6}$ konidia $\mathrm{ml}^{-1}$.

\section{Persiapan Benih Cabai}

Benih cabai yang digunakan dalam penelitian ini adalah varietas Unpad CB-2 yang diperoleh dari Laboratorium Pemuliaan Tanaman dan Produksi Tanaman yang merupakan koleksi Dr. Ir. Neni Rostini, MS. Tanaman cabai varietas Unpad CB-2 merupakan hasil persilangan Capsicum frutescens degan varietas UNPAD CB 1 yang keturunannya disilangkan dengan cabai keriting lokal kode seleksi 1-7-2-2 atau RM08 AXKRTRM 1B (Kementerian Pertanian, 2015).

\section{Infestasi $R$. minuta}

Benih cabai yang akan diberi perlakuan terlebih dahulu direndam dalam air hangat selama \pm 4 jam. Perlakuan dilakukan dengan merendam benih cabai tersebut dalam suspensi khamir $R$. minuta dengan kerapatan $10^{8}$ sel $\mathrm{ml}^{-1}$ selama 60 menit. Selanjutnya, benih diperam menggunakan kertas tissu steril lembab pada suhu ruang selama 12 jam. Benih untuk perlakuan kontrol, direndam dalam akuades steril.

Benih cabai yang telah diberi perlakuan, selanjutnya disemai pada media semai ready mixed media "Fam Organic" dalam polibag berukuran $10 \times 15 \mathrm{~cm}$. Media semai ini merupakan campuran dari tanah, sekam bakar, cocopeat dan pupuk kascing. Bibit berumur 5 minggu dipindah ke polibag berukuran 20x25 $\mathrm{cm}$ dan disiram kembali dengan suspensi khamir sebanyak $30 \mathrm{ml}$ per bibit (kerapatan $10^{8}$ sel $\mathrm{ml}^{-1}$ ). Media tanam yang digunakan untuk pindah tanam berupa campuran tanah dengan pupuk 
kandang sapi dengan perbandingan 2:1. Pemeliharaan tanaman dilakukan dengan cara menyiram tanaman setiap hari dan pemberian pupuk. Pupuk yang digunakan adalah pupuk urea sebanyak $1 \mathrm{~g}^{\text {polybag }}{ }^{-1}$ $\left(200 \mathrm{~kg} \mathrm{ha}^{-1}\right)$, Za sebanyak 2,25 polybag ${ }^{-1}$ (450 kg ha $\left.{ }^{1}\right), \mathrm{SP}_{36}$ sebanyak $0,75 \mathrm{~g}$ polybag $^{-1}\left(150 \mathrm{~kg} \mathrm{ha}^{-1}\right), \mathrm{KCl}$ sebanyak $0,75 \mathrm{~g}_{\text {polybag }}{ }^{-1}\left(150 \mathrm{~kg} \mathrm{ha}^{-1}\right)$ (Setiadi, 2006).

\section{Inokulasi $C$. acutatum}

Inokulasi $C$. acutatum pada cabai dilakukan sesuai rancangan perlakuan masing-masing yaitu dengan waktu inokulasi 3, 5, 7, dan 10 hari setelah pindah tanam (hst). Daun cabai yang muda sebanyak empat daun dilukai dengan menggunakan jarum steril. Inokulasi dilakukan dengan meneteskan suspensi $C$. acutatum sebanyak $0,1 \mathrm{ml} \mathrm{daun}^{-1}$ dengan kerapatan $10^{6}$ konidia $\mathrm{ml}^{-1}$. Tanaman yang telah diinokulasi disungkup menggunakan kantung plastik.

\section{Pengamatan Pertumbuhan Tanaman}

Pengamatan terhadap pertumbuhan tanaman dilakukan terhadap tinggi tanaman cabai, jumlah daun, dan bobot tanaman kering. Tinggi tanaman diukur mulai pangkal batang sampai tajuk tanaman tertinggi menggunakan penggaris. Jumlah daun dihitung pada masing-masing tanaman dalam perlakuan. Tinggi tanaman dan jumlah daun cabai diukur dan dihitung selama 3 kali pengamatan. Bobot biomasa kering diukur setelah tanaman dioven selama 2 hari. Pengamatan bobot biomasa kering dilakukan 1 kali pada akhir pengamatan. Data tinggi tanaman, jumlah daun, dan bobot biomasa kering dihitung keefektifannya terhadap kontrol, dengan menggunakan rumus sebagai berikut:

$$
\text { Eip }=\frac{l p-l k}{l p} \times 100 \%
$$

Eip $=$ Keefektifan pertambahan pertumbuhan tanaman $1_{p}=$ Pertumbuhan tanaman dengan perlakuan khamir $1_{\mathrm{k}}=$ Pertumbuhan tanaman kontrol (-)

\section{Analisis Data}

Data hasil pengujian dianalisis dengan Analysis of Variance (ANOVA) dengan menggunakan program SPSS Versi 22.0 for windows. Jika terdapat pengaruh perlakuan maka dilakukan uji lanjut dengan Uji Jarak Berganda Duncan pada taraf nyata $5 \%$.

\section{HASIL DAN PEMBAHASAN}

\section{Pengaruh Perlakuan $R$. minuta terhadap Tinggi Tanaman Cabai}

Berdasarkan hasil analisis statistika, perlakuan perendaman benih dan penyiraman bibit cabai dengan $R$. minuta tidak berpengaruh terhadap tinggi tanaman cabai. Hasil pengukuran tinggi tanaman cabai pada umur 4, 5, 6, 7 dan 8 minggu menunjukkan nilai yang tidak berbeda jauh antar perlakuan (Tabel 1). Walaupun demikian, terdapat kecenderungan cabai lebih tinggi pada perlakuan dibandingkan dengan kontrol.

Berdasarkan nilai keefektifan peningkatan tinggi tanaman cabai, perlakuan infestasi $R$. minuta menghasilkan nilai keefektifan positif (Tabel 2). Nilai keefektifan peningkatan tinggi tanaman yang dihasilkan berkisar antara 11,47-13,46\% (Tabel 2). Pada cabai tanpa infestasi $R$. minuta tetapi diinokulasi C. acutatum, nilai keefektifan peningkatan tinggi tanaman bernilai negatif. Hal ini menunjukkan bahwa inokulasi C. acutatum tanpa perlakuan infestasi $R$. minuta dapat menurunkan tinggi tanaman cabai. Rata-rata nilai keefektifan peningkatan tinggi tanaman cabai tertinggi terjadi pada perlakuan infestasi $R$. minuta dengan waktu inokulasi C. acutatum 7 hst.

\section{Pengaruh Perlakuan Investasi $R$. minuta terhadap Jumlah Daun Cabai}

Berdasarkan hasil analisis statistika, diketahui bahwa perlakuan infestasi $R$. minuta tidak berpengaruh terhadap jumlah daun cabai. Masingmasing perlakuan infestasi $R$. minuta dan inokulasi $C$. acutatum yang diberikan menghasilkan jumlah daun yang hampir sama pada setiap pengamatan (Tabel 3). Akan tetapi, jumlah daun cabai pada pengamatan 4, 5, 6, 7, 8 minggu setelah tanam (mst) cenderung meningkat pada perlakuan infestasi $R$. minuta dibandingkan dengan tanpa infestasi tetapi diinokulasi patogen (Tabel 3).

Keefektifan peningkatan jumlah daun cabai menunjukkan bahwa perlakuan infestasi $R$. minuta memiliki nilai keefektifan positif, sedangkan pada cabai yang diinokulasi patogen tanpa infestasi agens biokontrol keefektifan peningkatan jumlah daun bernilai negatif. Nilai keefektifan peningkatan jumlah daun pada perlakuan infestasi $R$. minuta berkisar antara 5,90-8,24\% (Tabel 4). Rata-rata nilai keefektifan peningkatan jumlah daun tertinggi terjadi pada perlakuan infestasi $R$. minuta dengan waktu inokulasi C. acutatum 7 hst (Tabel 4).

\section{Pengaruh Perlakuan Investasi $\boldsymbol{R}$. minuta terhadap Bobot biomasa Kering}

Hasil analisis statistika terhadap bobot biomasa kering menunjukkan bahwa perlakuan infestasi $R$. minuta tidak berpengaruh terhadap bobot biomasa kering tanaman cabai pada umur 8 minggu setelah tanam (mst). Hasil pengukuran bobot biomasa kering pada 8 mst menunjukkan nilai yang tidak berbeda jauh antar perlakuan (Tabel 5).

Berdasarkan perhitungan nilai keefektifan peningkatan bobot biomasa kering, perlakuan infestasi $R$. minuta menghasilkan nilai keefektifan peningkatan bobot biomasa kering positif (Tabel 6). Nilai keefektifan peningkatan bobot biomasa kering pada perlakuan infestasi $R$. minuta berkisar antara 0,14$0,58 \%$, dengan nilai keefektifan peningkatan bobot biomasa kering tertinggi terjadi pada perlakuan infestasi R. minuta dengan inokulasi C acutatum 7 hst (Tabel 6). 
Tabel 1. Tinggi tanaman cabai dengan perlakuan infestasi $R$. minuta

\begin{tabular}{|c|c|c|c|c|c|c|}
\hline \multirow{2}{*}{\multicolumn{2}{|c|}{ Perlakuan }} & \multicolumn{5}{|c|}{$\begin{array}{l}\text { Tinggi tanaman }(\mathrm{cm}) \\
\text { pada pengamatan }(\mathrm{mst})\end{array}$} \\
\hline & & 4 & 5 & 6 & 7 & 8 \\
\hline Infestasi $R$. minuta, inokulasi $C$. acutatum $3 \mathrm{hst}$ & & 8,48 & 9,10 & 9,62 & 10,14 & 12,10 \\
\hline Infestasi $R$. minuta, inokulasi $C$. acutatum $5 \mathrm{hst}$ & & 8,84 & 9,28 & 9,92 & 10,48 & 11,86 \\
\hline Infestasi $R$. minuta, inokulasi $C$. acutatum 7 hst & & 8,26 & 9,16 & 9,76 & 10,62 & 12,70 \\
\hline Infestasi $R$. minuta, inokulasi $C$. acutatum $10 \mathrm{hst}$ & & 8,16 & 9,20 & 10,06 & 11,06 & 12,30 \\
\hline $\begin{array}{l}\text { Kontrol + (Tanpa Infestasi } R . \text { minuta, inokulasi } \\
\text { acutatum } 3 \text { hst) }\end{array}$ & $C$ & 7,04 & 7,62 & 8,26 & 9,36 & 10,78 \\
\hline $\begin{array}{l}\text { Kontrol + (Tanpa infestasi } R \text {. minuta, inokulasi } \\
5 \text { hst) }\end{array}$ & C. acutatum & 7,12 & 7,58 & 8,16 & 9,3 & 10,84 \\
\hline $\begin{array}{l}\text { Kontrol + (Tanpa infestasi } R \text {. minuta, inokulasi } \\
7 \text { hst) }\end{array}$ & C. acutatum & 7,02 & 7,36 & 8,32 & 9,7 & 10,72 \\
\hline $\begin{array}{l}\text { Kontrol + (Tanpa infestasi } R \text {. minuta, inokulasi } \\
10 \text { hst }\end{array}$ & C. acutatum & 7,08 & 7,52 & 7,94 & 9,08 & 10,70 \\
\hline $\begin{array}{l}\text { Kontrol - (Tanpa infestasi } R \text {. minuta dan inokulas } \\
\text { C.acutatum) }\end{array}$ & & 7,06 & 7,46 & 8,38 & 9,64 & 10,84 \\
\hline
\end{tabular}

Keterangan: mst: minggu setelah tanam, hst: hari setelah pindah tanam Nilai kk: 5.423603

Tabel 2. Keefektifan peningkatan tinggi tanaman cabai dengan perlakuan infestasi $R$. minuta

\begin{tabular}{|c|c|c|c|c|c|c|}
\hline \multirow[t]{2}{*}{ Perlakuan } & \multicolumn{5}{|c|}{$\begin{array}{l}\text { Keefektifan peningkatan jumlah daun (Eip) (\%) } \\
\text { pada pengamatan (mst) }\end{array}$} & \multirow{2}{*}{$\begin{array}{c}\text { Rata-rata } \\
(\%)\end{array}$} \\
\hline & 4 & 5 & 6 & 7 & 8 & \\
\hline Infestasi $R$. minuta, inokulasi $C$. acutatum $3 \mathrm{hst}$ & 16,18 & 16,77 & 11,76 & 3,78 & 9,94 & 11,69 \\
\hline Infestasi $R$. minuta, inokulasi $C$. acutatum $5 \mathrm{hst}$ & 17,62 & 16,77 & 11,97 & 4,34 & 6,63 & 11,47 \\
\hline Infestasi $R$. minuta, inokulasi $C$. acutatum 7 hst & 13,54 & 17,90 & 13,69 & 8,21 & 13,94 & 13,46 \\
\hline Infestasi $R$. minuta, inokulasi $C$. acutatum 10 hst & 12,57 & 15,98 & 14,04 & 11,25 & 9,82 & 12,73 \\
\hline $\begin{array}{l}\text { Kontrol + (Tanpa Infestasi } R \text {. minuta, inokulasi } C \text {. } \\
\text { acutatum } 3 \text { hst) }\end{array}$ & $-3,88$ & $-1,00$ & $-3,74$ & $-4,69$ & $-0,78$ & $-2,82$ \\
\hline $\begin{array}{l}\text { Kontrol + (Tanpa infestasi } R \text {. minuta, inokulasi } C \text {. } \\
\text { acutatum } 5 \text { hst) }\end{array}$ & $-5,14$ & $-1,60$ & $-5,81$ & $-6,62$ & $-3,64$ & $-4,56$ \\
\hline $\begin{array}{l}\text { Kontrol + (Tanpa infestasi } R \text {. minuta, inokulasi } C \text {. } \\
\text { acutatum } 7 \text { hst) }\end{array}$ & $-4,88$ & $-4,54$ & $-3,86$ & $-0,51$ & $-1,41$ & $-3,04$ \\
\hline $\begin{array}{l}\text { Kontrol + (Tanpa infestasi } R \text {. minuta, inokulasi } C \text {. } \\
\text { acutatum } 10 \mathrm{hst}\end{array}$ & $-0,99$ & $-0,15$ & $-6,24$ & $-6,07$ & $-1,49$ & $-2,99$ \\
\hline
\end{tabular}

Keterangan: mst: minggu setelah tanam, hst: hari setelah pindah tanam

Tabel 3. Jumlah daun cabai dengan perlakuan infestasi $R$. minuta

\begin{tabular}{|c|c|c|c|c|c|}
\hline \multirow[t]{2}{*}{ Perlakuan } & \multicolumn{5}{|c|}{$\begin{array}{l}\text { Jumlah daun tanaman cabai pada } \\
\text { pengamatan (mst) }\end{array}$} \\
\hline & 4 & 5 & 6 & 7 & 8 \\
\hline Infestasi $R$. minuta, inokulasi $C$. acutatum 3 hst & 6,2 & 7,2 & 8 & 9,2 & 10,8 \\
\hline Infestasi $R$. minuta, inokulasi $C$. acutatum 5 hst & 6,4 & 7,2 & 8,2 & 9,2 & 10,8 \\
\hline Infestasi $R$. minuta, inokulasi $C$. acutatum $7 \mathrm{hst}$ & 6,6 & 7,4 & 8,2 & 9,6 & 10,6 \\
\hline Infestasi $R$. minuta, inokulasi $C$. acutatum $10 \mathrm{hst}$ & 6,4 & 7,2 & 8,2 & 9,4 & 10,8 \\
\hline Kontrol + (Tanpa Infestasi $R$. minuta, inokulasi $C$. acutatum $3 \mathrm{hst})$ & 5,6 & 6,6 & 7,4 & 8,8 & 9,6 \\
\hline Kontrol + (Tanpa infestasi $R$. minuta, inokulasi $C$. acutatum $5 \mathrm{hst})$ & 5,6 & 6,8 & 7,4 & 8,4 & 9,4 \\
\hline Kontrol + (Tanpa infestasi $R$. minuta, inokulasi $C$. acutatum $7 \mathrm{hst})$ & 5,6 & 6,8 & 7,4 & 8,6 & 9,6 \\
\hline Kontrol + (Tanpa infestasi $R$. minuta, inokulasi $C$. acutatum 10 hst & 5,4 & 6,6 & 7,4 & 8,6 & 9,6 \\
\hline Kontrol - (Tanpa infestasi $R$. minuta dan inokulasi C.acutatum) & 5,6 & 6,8 & 7,6 & 8,8 & 10 \\
\hline
\end{tabular}

Keterangan: mst: minggu setelah tanam, hst: hari setelah pindah tanam Nilai kk: 7.916498 
Tabel 4. Keefektifan peningkatan jumlah daun cabai dengan perlakuan infestasi $R$. minuta

\begin{tabular}{|c|c|c|c|c|c|c|}
\hline \multirow[t]{2}{*}{ Perlakuan } & \multicolumn{5}{|c|}{$\begin{array}{l}\text { Keefektifan peningkatan jumlah daun } \\
\text { (Eip) }(\%) \text { pada pengamatan (mst) }\end{array}$} & \multirow{2}{*}{$\begin{array}{l}\text { Rata-rata } \\
\qquad \%)\end{array}$} \\
\hline & 4 & 5 & 6 & 7 & 8 & \\
\hline Infestasi $R$. minuta, inokulasi $C$. acutatum 3 hst & 10,19 & 4,72 & 4,09 & 4,50 & 7,00 & 6,10 \\
\hline Infestasi $R$. minuta, inokulasi $C$. acutatum 5 hst & 11,86 & 4,09 & 5,00 & 4,06 & 6,48 & 6,30 \\
\hline Infestasi $R$. minuta, inokulasi $C$. acutatum 7 hst & 15,19 & 7,30 & 5,95 & 8,22 & 4,53 & 8,24 \\
\hline Infestasi $R$. minuta, inokulasi $C$. acutatum $10 \mathrm{hst}$ & 12.69 & 4,72 & 5,87 & 6,04 & 6,97 & 5,90 \\
\hline $\begin{array}{l}\text { Kontrol + (Tanpa Infestasi } R \text {. minuta, inokulasi } \\
\text { C. acutatum } 3 \text { hst) }\end{array}$ & $-1,14$ & $-3,69$ & $-6,94$ & $-4,25$ & $-6,13$ & $-4,43$ \\
\hline $\begin{array}{l}\text { Kontrol + (Tanpa infestasi } R \text {. minuta, inokulasi } \\
\text { C. acutatum } 5 \text { hst) }\end{array}$ & $-3,14$ & $-3,60$ & $-5,71$ & $-5,28$ & $-8,31$ & $-5,21$ \\
\hline $\begin{array}{l}\text { Kontrol + (Tanpa infestasi } R \text {. minuta, inokulasi } \\
\text { C. acutatum } 7 \text { hst) }\end{array}$ & $-0,48$ & $-2,89$ & $-6,27$ & $-4,06$ & $-6,09$ & $-3,96$ \\
\hline $\begin{array}{l}\text { Kontrol + (Tanpa infestasi } R \text {. minuta, inokulasi } \\
\text { C. acutatum } 10 \mathrm{hst}\end{array}$ & $-3,33$ & $-4,36$ & $-3,49$ & $-3,59$ & $-5,50$ & $-4,05$ \\
\hline
\end{tabular}

Keterangan: mst: minggu setelah tanam, hst: hari setelah pindah tanam

Tabel 5. Bobot biomasa kering tanaman cabai dengan perlakuan $R$. minuta pada umur $8 \mathrm{mst}$

\begin{tabular}{|c|c|}
\hline Perlakuan & Bobot kering $(\mathrm{g})$ \\
\hline Infestasi $R$. minuta, inokulasi $C$. acutatum 3 hst & 2,37 \\
\hline Infestasi $R$. minuta, inokulasi $C$. acutatum 5 hst & 2,37 \\
\hline Infestasi $R$. minuta, inokulasi $C$. acutatum 7 hst & 2,38 \\
\hline Infestasi $R$. minuta, inokulasi $C$. acutatum $10 \mathrm{hst}$ & 2,37 \\
\hline Kontrol + (Tanpa Infestasi $R$. minuta, inokulasi $C$. acutatum $3 \mathrm{hst})$ & 2,35 \\
\hline Kontrol + (Tanpa infestasi $R$. minuta, inokulasi $C$. acutatum 5 hst $)$ & 2,32 \\
\hline Kontrol + (Tanpa infestasi $R$. minuta, inokulasi $C$. acutatum $7 \mathrm{hst})$ & 2,32 \\
\hline Kontrol + (Tanpa infestasi $R$. minuta, inokulasi $C$. acutatum $10 \mathrm{hst}$ & 2,31 \\
\hline Kontrol - (Tanpa infestasi $R$. minuta dan inokulasi C.acutatum) & 2,36 \\
\hline
\end{tabular}

Keterangan: mst: minggu setelah tanam, hst: hari setelah pindah tanam

Nilai kk: 2.124059

Tabel 6. Keefektifan peningkatan bobot biomasa kering tanaman cabai dengan perlakuan infestasi $R$. minuta pada umur $8 \mathrm{mst}$

\begin{tabular}{|c|c|}
\hline Perlakuan & $\begin{array}{l}\text { Keefektifan peningkatan bobot kering } \\
\text { tanaman (Eip) }(\%)\end{array}$ \\
\hline Infestasi $R$. minuta, inokulasi $C$. acutatum 3 hst & 0,15 \\
\hline Infestasi $R$. minuta, inokulasi $C$. acutatum 5 hst & 0,14 \\
\hline Infestasi $R$. minuta, inokulasi $C$. acutatum 7 hst & 0,58 \\
\hline Infestasi $R$. minuta, inokulasi $C$. acutatum $10 \mathrm{hst}$ & 0,41 \\
\hline $\begin{array}{l}\text { Kontrol + (Tanpa Infestasi } R \text {. minuta, inokulasi } C \text {. } \\
\text { acutatum } 3 \text { hst) }\end{array}$ & $-0,56$ \\
\hline $\begin{array}{l}\text { Kontrol + (Tanpa infestasi } R \text {. minuta, inokulasi } C \text {. } \\
\text { acutatum } 5 \text { hst) }\end{array}$ & $-2,00$ \\
\hline $\begin{array}{l}\text { Kontrol + (Tanpa infestasi } R \text {. minuta, inokulasi } C \text {. } \\
\text { acutatum } 7 \text { hst) }\end{array}$ & $-1,85$ \\
\hline $\begin{array}{l}\text { Kontrol + (Tanpa infestasi } R \text {. minuta, inokulasi } C \text {. } \\
\text { acutatum } 10 \mathrm{hst}\end{array}$ & $-2,43$ \\
\hline
\end{tabular}

Keterangan: mst: minggu setelah tanam, hst: hari setelah pindah tanam

Waqas et al. (2012) menyatakan bahwa pertumbuhan tanaman dapat dipicu oleh mikrob, baik secara langsung maupun tidak langsung. Pengaruh mikrob terhadap pertumbuhan tanaman secara langsung yaitu dengan menghasilkan zat pengatur tumbuh atau meningkatkan ketersediaan nutrisi yang terbatas untuk pertumbuhan tanaman (Waqas et al., 2012), sedangkan secara tidak langsung mikrob menekan gangguan patogen (Manici et al., 2014).

Menurut Deval et al. (2001) mikrob mampu menghasilkan senyawa metabolit sekunder dan masing-masing spesies mikrob menghasilkan senyawa 
metabolit sekunder yang berbeda. Senyawa metabolit sekunder dapat berperan sebagai fitohormon. Fitohormon yang paling umum diketahui berperan dalam pertumbuhan dan perkembangan tanaman adalah Indole-3-Acetic Acid (IAA) dan Indole-3Pyruvic Acid (IPYA) (Teale et al., 2006). Beberapa khamir telah dilaporkan mampu menghasilkan senyawa metabolit sekunder yang berperan sebagai fitohormon. Khamir Aureobasidium pullulans mampu menghasilkan IAA sebagai salah satu metabolit sekunder yang berperan dalam peningkatan pertumbuhan tanaman (Ignatova et al., 2015). Selain itu, beberapa khamir lain juga telah dilaporkan mampu menghasilkan IAA yaitu Cryptocococcus flavus (Naratat et al., 2014), Saccharomyces, Cryptococcus, dan Candida (Lasmini, 2016). Khamir Williopsis saturnus menghasilkan IPYA sebagai metabolit sekunder yang berperan dalam peningkatan pertumbuhan tanaman (Nassar et al., 2005).

Nassar et al. (2005) melaporkan bahwa $R$. minuta mampu menghasilkan hormon pertumbuhan IAA. Tidak berpengaruhnya perlakuan $R$. minuta terhadap pertumbuhan tanaman cabai pada penelitian ini diduga disebabkan $R$. minuta hanya sedikit menghasilkan hormon pertumbuhan. Akan tetapi, adanya nilai keefektifan positif pada perlakuan $R$. minuta diduga karena adanya pengaruh mekanisme antagonisme $R$. minuta terhadap $C$. acutatum, sehingga infeksi patogen ini terhadap tanaman menjadi terhambat. $R$. minuta telah dilaporkan mampu menekan antraknosa yang disebabkan oleh $C$. acutatum sebesar 90,17\% melalui mekanisme secara langsung (Hartati, 2016), dan melalui mekanisme induksi resistensi sebesar 47,33\% (Tarina, 2019). Terhambatnya infeksi patogen dapat menghambat terjadinya kerusakan tanaman yang akhirnya berpengaruh terhadap pertumbuhan tanaman. Yunasfi (2008) menyatakan bahwa infeksi patogen pada tanaman dapat menyebabkan gangguan terhadap proses fotosintesis sehingga dapat menghambat pertumbuhan tanaman. Serangan patogen menyebabkan terjadinya perubahan dan fungsi kloroplas menjadi tidak normal, juga dapat menyebabkan terjadinya reduksi rRNA yang menyebabkan terjadinya penurunan aktivitas ribosom (Yunasfi, 2008). Berdasarkan hasil penelitian ini diperlukan penambahan frekuensi perlakuan $R$. minuta pada fase pertumbuhan vegetatif dan generatif tanaman. Aplikasi $R$. minuta pada penelitian ini hanya dilakukan sebanyak 2 kali yaitu pada benih dan saat pindah tanam.

\section{KESIMPULAN}

Khamir $R$. minuta mampu memacu pertumbuhan tanaman cabai yang terinfeksi $C$. acutatum berdasarkan nilai keefektifan pertumbuhan tanaman melalui peningkatan tinggi tanaman, jumlah daun, dan bobot biomasa kering. Nilai keefektifan peningkatan pertumbuhan cabai tertinggi dengan perlakuan infestasi $R$. minuta adalah sebesar $17,90 \%$ untuk tinggi tanaman, 15,19\% untuk jumlah daun, dan $0,58 \%$ untuk bobot biomasa kering.

\section{UCAPAN TERIMAKASIH}

Terimakasih disampaikan kepada Universitas Padjadjaran atas dukungan dana penelitian Hibah Internal Unpad (HIU) tahun anggaran 2018.

\section{DAFTAR PUSTAKA}

Alami, N. H., S. A. T. Ayu, N. D. Kuswytasari, E. Zulaika, \& M. Shovitri. 2017. Effect of yeast based biofertilizer combined with bacteria on mustard plant growth. Intern. J. Appl. Biol. 1(2): 46-57.

Amprayn, K.O., M.T. Rose, M. Kecskes, L. Pereg, H.T. Nguyen, \& I.R. Kennedy, 2012. Growth promoting characteristics of soil yeast (Candida tropicalis HY) and its effectiveness for promoting rice growth. J. Appl. Soil. Ecol. 61: 295-299.

Deval, A. G., A. Platas, A. Basilio, J. Gorrochategui, I. Suay, F. Vicente, E. Portillo, M.J. Del Rio, G.G. Reina \& F. Pelaez. 2001. Screening of antimicrobial activities in red, green and brown macroalgae from Gran Canaria (Canary Islands, Spain). Intern.Microbiol. 4: 35-40.

Duriat, A. \& M. Agus. 2003. Pengenalan Penyakit Penting Pada Cabai dan Pengendaliannya Berdasarkan Epidemologi Terapan. Lembang: Balai Penelitian Tanaman Sayuran.

Fu, S.-F., Sun P.-F., Lu H.-Y., Wei J.-Y., Xiao, H.-S., Fang W.-T., Cheng, B.-Y, Chou, J.-Y. 2016. Plant growth-promoting traits of yeasts isolated from the phyllosphere and rhizosphere of Drosera spatulata Lab. Fungal Biol. 120: 433-448.

Hartati, S. 2016. Khamir sebagai Agens Biokontrol Antraknosa (Colletotrichum acutatum J. H. Simmonds) pada Cabai Pascapanen. [Disertasi]. Bogor: Sekolah Pascasarjana Institut Pertanian Bogor.

Ignatova, L.V., Y.V. Brazhnikova, R.Z. Berzhanova \& T.D. Mukasheva. 2015. Plant growthpromoting and antifungal activity of yeasts from dark chesnut soil. Microbiol. Res. 175:78-83.

Kementerian Pertanian. 2015. Deskripsi Cabai Varietas Unpad CB-2. Surat Keputusan Menteri Pertanian Nomor 032/Kpts/SR.120/D. 2. 7/3/2015.

Lasmini, T. 2016. Isolasi dan identifikasi khamir penghasil asam indol asetat dari rhizosfer anggrek tanah Pecteilis susannae (L.) Rafin. Jurnal IPTEKS Terapan Research of Appl. Sci. and Edu. 9(4):261-268.

Manici, L.M., M. Kelderer, F. Caputo \& M. Mazzol. 2014. Auxin-mediated relationships between apple plants and root inhabiting fungi: 
Impact on root pathogens and potentialities of growth-promoting populations. Plant Pathol. 64(4):851-43.

Naratat, P., N. Srisuk, P. Arunrattiyakorn \& S. Limtong. 2014. Plant growth-promoting traits of epiphytic and endophytic yeasts isolated from rice and sugar cand leaves in Thailand. J.Fungal Biol. 118(8):683-694.

Nassar, A. H., K.A. El-Tarabily \& K. Sivasithamparam. 2005. Promotion of plant growth by an auxin-producing isolate of the yeast Williopsis saturnus endophytic in maize (Zea mays L.) roots. Biol.Ferti.Soils. 42(2):97-108.

Nayaka, S.C., A.C.U. Shankar, S.R. Niranjana, H.S. Prakash \& C.N. Mortensen. 2009. Anthracnose disease of chilli pepper. Techn Bull. India (IN): The Asian Seed Health Centre (AsSHC), Department of Studies in Applied Botany \& Biotechnology, University of Mysore, Manasagangotri, Mysore 570006, Karnataka, India. p. 1-13.

Setiadi. 2006. Bertanam Cabai. Jakarta: Penebar Swadaya. $184 \mathrm{hlm}$.

Stankova B, J. Vichova, \& R. Pokorny. 2011. Virulence of Colletotrichum acutatum isolates to several host plants. Acta univ agric et silvic Mendel Brun. LIX(3):161-170.
Sundaramoorthy, S. \& P. Balabaskar. 2013. Biocontrol efficacy of Trichoderma spp. against wilt of tomato caused by Fusarium oxysporum f.sp. lycopersici. J. Appl. Biol.Biotech. 1(3):36-40.

Tarina, L. 2019. Induksi Resistensi Tanaman Cabai terhadap Patogen Penyebab Antraknosa (Colletotrichum acutatum J. H. Simmonds) dengan Khamir Rhodotorula minuta Saito. [Skripsi] Fakultas Pertanian, Universitas Padjadjaran.

Teale, W. D., I. A. Paponov \& K. Palme. 2006. Auxin in action: Signalling, transport and the control of plant growth and development. Nat. Rev. Molec. Cell Biol. 7: 847-859.

Waqas, M., A.L. Khan, M.Kamran, M. Hamayun, S.M. Kang, Y.H. Kim, \& In-Jung Lee. 2012. Endophytic fungi produce gibberellins and indoleacetic acid and promotes host-plant growth during stress. Molecules. 17:1075410773.

Yunasfi. 2008. Serangan Patogen dan Gangguan terhadap Proses Fisiologis Pohon. Departemen Kehutanan, Fakultas Pertanian, Sumatera Utara.

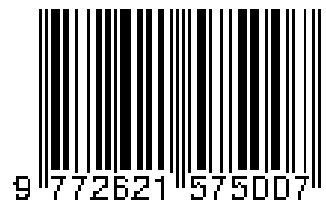

